\title{
Rectus fascia pubovaginal sling for recurrent stress urinary incontinence after failed synthetic mid-urethral sling: Letter
}

\author{
Colin A. Walsh, MRCOG; Katrina Parkin, RN; Kate H. Moore, MD, FRANZCOG
}

Pelvic Floor Unit, St George Hospital, University of New South Wales, Sydney, Australia

Cite as: Can Urol Assoc J 2012;6(6):429-30. hitp://dx.doi.org/10.5489/cuaj.12132

W e were very interested to read the recent study by Welk and Herschorn, and the related commentary by Steele, regarding the role of autologous rectus fascial slings for complex recurrent female stress urinary incontinence (SUI). ${ }^{1,2}$ The authors report that, on mediumterm follow-up of 33 women with previous failed continence surgery, pubovaginal sling was associated with a significant reduction in pad usage and good patient satisfaction rates. ${ }^{1}$

In 2010, we reviewed the published literature on therapeutic options for managing women with recurrent SUI after failed synthetic mid-urethral sling (MUS). ${ }^{3}$ At that time, no studies reporting outcomes after PVS for a previous failed MUS had been reported and thus, the data reported by Welk and Herschorn are particularly welcome. We also recently collected data on women undergoing rectus fascial PVS for complex recurrent SUI in our tertiary urogynecology unit. Preoperative video-urodynamics was performed in all women considering PVS. The surgical technique used was very similar to that by Welk and Herschorn, ${ }^{1}$ with a $13 \times 2$-cm strip of rectus fascia harvested. All cases were seen in the clinic at 6 weeks and 12 months postoperatively and at variable follow-up periods thereafter. At follow-up visits, uroflowmetry and post-void residual volume were performed and subjective cure of SUI was assessed.

We identified 7 women who underwent PVS after a previously failed MUS, who were contacted by telephone to complete the ICIQ-SF questionnaire ${ }^{4}$ and to ascertain cure (Table 1). Women had a median age of 61 (range: 41-73) years and were a complex group, with a median of 2 (range: 1-4) prior continence surgeries. All women completed the telephone survey and the median interval since the PVS was 5 years (range: $0.5-9$ years). The long-term failure rate following PVS for recurrent SUI in our population was $14 \%$ (1/7). This patient had preoperative voiding dysfunction and

\begin{tabular}{|c|c|c|c|c|c|c|c|c|c|c|c|c|}
\hline \multirow[t]{2}{*}{ Case } & \multirow[t]{2}{*}{ MUS } & \multirow[t]{2}{*}{$\begin{array}{c}\text { Interval } \\
\text { (years) }\end{array}$} & \multirow[t]{2}{*}{$\begin{array}{l}\text { Other SUI } \\
\text { treatment }\end{array}$} & \multirow[t]{2}{*}{ BMI } & \multicolumn{3}{|c|}{$\begin{array}{l}\text { Preoperative video- } \\
\text { urodynamics }\end{array}$} & \multirow[t]{2}{*}{$\begin{array}{l}\text { Postoperative } \\
\text { complications }\end{array}$} & \multicolumn{4}{|c|}{ Telephone follow-up } \\
\hline & & & & & DO & $\begin{array}{l}\text { PVR } \\
\text { (mL) }\end{array}$ & $\begin{array}{c}\mathrm{MUCP} \\
\left(\mathrm{cmH}_{2} \mathrm{O}\right)\end{array}$ & & $\begin{array}{l}\text { Time } \\
\text { (years) }\end{array}$ & ICIQ & OAB & SUI \\
\hline 1 & IVS & 1 & Bulking & 29 & $\mathrm{~N}$ & 0 & 18 & - & 9 & $3 / 21$ & $\mathrm{~N}$ & V. mild \\
\hline 2 & IVS & 4 & None & 21 & $\mathrm{~N}$ & 0 & 52 & - & 7.5 & $8 / 21$ & $\mathrm{Y}$ & $\mathrm{N}$ \\
\hline 3 & IVS & 6 & $\begin{array}{l}\text { Incontinence } \\
\text { pessary }\end{array}$ & 32 & $\mathrm{~N}$ & 0 & 25 & Pulmonary embolus & 6 & $3 / 21$ & $\mathrm{Y}$ & $\mathrm{N}$ \\
\hline 4 & IVS & 2 & Repeat IVS & 33 & Y & 200 & N/A & $\begin{array}{l}\text { Pre-existing voiding } \\
\text { dysfunction (CISC) }\end{array}$ & 4.5 & $19 / 21$ & $\mathrm{Y}$ & $\mathrm{Y}$ \\
\hline 5 & TVT-O & 2 & $\begin{array}{l}\text { Colposuspension } \\
\& \text { bulking }(x 2)\end{array}$ & 27 & $\mathrm{~N}$ & 40 & 11 & UTI, fever & 3 & $7 / 21$ & $\mathrm{Y}$ & $\mathrm{N}$ \\
\hline 6 & TVT & 4 & $\begin{array}{l}\text { Pessary \& } \\
\text { bulking }\end{array}$ & 27 & $\mathrm{Y}$ & 30 & 25 & - & 2 & $0 / 21$ & $\mathrm{~N}$ & $\mathrm{~N}$ \\
\hline 7 & TVT & 5 & $\begin{array}{l}\text { Colposuspension } \\
\text { \& pessary }\end{array}$ & 28 & $\mathrm{~N}$ & 0 & 29 & $\begin{array}{l}\text { De novo voiding } \\
\text { dysfunction (CISC) }\end{array}$ & 0.5 & $19 / 21$ & $\mathrm{Y}$ & $\mathrm{N}$ \\
\hline
\end{tabular}


was still requiring self-catheterizing 4.5 years after the PVS. A second patient required self-catheterization for de novo voiding dysfunction but was dry.

Overall, 71\% (5/7) of women were completely cured and $86 \%(6 / 7)$ were satisfied. The rate of de novo OAB in women with a stable bladder preoperatively was $80 \%(4 / 5)$. One woman, with a history of known thrombophilia, suffered a large pulmonary embolus on postoperative day 12 but recovered fully.

We agree with the comments of Steele that autologous PVS still has a role as a salvage procedure in complex recurrent female SUI. We found that PVS was associated with a low failure rate, but a high rate of de novo OAB at 5 years in a small population of women with previous failed synthetic MUS. Although the case of pulmonary embolus in our population raises some concern, previous work from the Urinary Incontinence Treatment Network reported a low rate $(0.3 \%)$ of venous thromboembolism after PVS, which is reassuring. ${ }^{5}$

\section{References}

1. Welk BK, Herschorn $S$. The autologous fascia pubovaginal sling for complicated female stress incontinence. Can Urol Assoc J 2012;6:36-40. http://dx.doi.org/10.5489/cuaj.11117

2. Steele SS. Is there still a role for pubovaginal slings in the treatment of SUI in the era of mid-urethral slings? Can Urol Assoc J 2012;6:41. hittp://dx.doi.org/10.5489/cuaj.12011

3. Walsh CA, Moore KH. Recurrent stress urinary incontinence after synthetic midurethral sling procedure. Obstet Gynecol 2010;115:1296-301. http://dx.doi.org/10.1097/A0G.0b013e3181da3a48

4. Avery K, Donovan J, Abrams P. Validation of a new questionnaire for incontinence: the International Consultation on Incontinence Questionnaire (ICIQ). Neurourol Urodyn 2001;20:510-2.

5. Albo ME, Richter HE, Brubaker L, et al. Burch colposuspension versus fascial sling to reduce urinary stress incontinence. N Engl J Med 2007;356:2143-55. http://dx.doi.org/10.1056/NEJMoa070416

Correspondence: Professor Kate Moore, Pitney Clinical Sciences Building, St. George Hospital, Kogarah, Sydney, NSW 2217, Australia; k.moore@unsw.edu.au

\title{
The role of the surgeon in managing patients with midurethral slings: Response
}

\author{
Blayne Welk, MD, FRCSC, MSc
}

Assistant Professor, Division of Urology, Western University, London, ON

Cite as: Can Urol Assoc J 2012;6(6):429. http://dx.doi.org/10.5489/cuaj.12318

$\mathrm{T}$ here is currently little evidence available to guide surgeons on the management of a patient with a failed midurethral sling. ${ }^{1}$ The reported results by Walsh and colleagues suggest a pubovaginal sling is effective at treating stress incontinence after a failed midurethral sling. ${ }^{2}$ In our cohort of patients, ${ }^{3}$ 16/33 had a previous midurethral sling, and half of these had experienced a vaginal or urethral erosion. The subset of patients who had recurrent incontinence after a previous midurethral sling showed a trend towards better outcomes compared patients undergoing a pubovaginal sling for other reasons, (median 0 (interquartile range [IQR]: 0-3) versus median 3 (IQR: 1-5) pads per day, $p=0.12$ ).

The management of patients who have failed a midurethral sling or suffered significant complications from one will continue to be challenging. The autologous fascia pubovaginal sling continues to have a role in the management of patients with complex stress incontinence.

\section{References}

1. Gormley EA. Evaluation and management of the patient with a failed midurethral synthetic sling. Can Urol Assoc J 2012;6:S123-4. http://dx.doi.org/10.5489/cuaj.12011

2. Walsh CA, Parkin K, Moore KH. Rectus fascia pubovaginal sling for recurrent stress urinary incontinence ofter failed synthetic mid-urethral sling: Letter. Can Urol Assoc J 2012;6:429-30. http://dx.doi. org/10.5489/cuaj.12132

3. Welk BK, Herschorn S. The autologous fascia pubovaginal sling for complicated female stress incontinence. Can Urol Assoc J 2012;6:36-40. htrp://dx.doi.org/10.5489/cuaj.11117

Correspondence: Dr. Blayne Welk, Division of Urology, Western University, Room B4-667, St Joseph's Health Care, 268 Grosvenor St., London ON N6A 4V2; fax: 519-646-6037; bkwelk@gmail.com 